\title{
MODELLING SOIL LOSSES FROM THE ARDECHE RANGELANDS
}

\author{
J.M. Roels, Utrecht
}

\begin{abstract}
A simple equation is needed to predict soil loss on a storm-by-storm basis and on a hillslope scale. In response to this need a modelling procedure is proposed that incorporates not only the relation between soil loss and one or more determining factors at individual locations in different source areas (interrill, pre-rill and rill areas) but also the spatial variation in this relation among locations within a source area. The initial version of the relation presented here considers soil loss only as a function of erosivity and rainfall and runoff erosivity factors are used for interrill areas and for pre-rill and rill areas respectively. About $85 \%$ of the variation in soil loss at individual locations in each source area is explained by erosivity. The influence of erosivity, however, is found to vary with the size of the area under consideration. In addition, this scale-dependence varies with the type of erosion occurring. Modelling soil loss becomes much more effective if this effect is taken into account.

The rainsplash and interrill erosion equations presented are very site-specific. This means that modelling these types of erosion on a hillslope scale will involve the introduction of many erosion determining factors. The rill and pre-rill erosion equations are less sitespecific. Accordingly, fewer factors are required to describe these erosion types. On a hillslope scale a pre-rill erosion model for instance based only on erosivity can explain as much as $76 \%$ of the variation in soil loss.
\end{abstract}

\section{INTRODUCTION}

Since the late 1960 's considerable research has been carried out in order to develop a flexible and accurate soil loss equation to replace the Universal Soil Loss Equation - USLE (MEYER \& WISCHMEIER 1969, FOSTER et al. 1977a, b). Researchers have recognized that soil loss from a given slope, which is being controlled by either the soil detachment capacity or by the sediment transport capacity, depends on the influence of topography, soil, vegetation and rainfall-runoff characteristics, which varies over time. The influence of each factor varies on different time scales. Therefore soil loss predictions relating to individual storms are needed, and lumped equations (such as the USLE) are unsuitable for making such predictions.

In the past, erosion studies usually have not taken into account whether the soil that was eroded from upland slopes originated from the soil surface or from beneath it, whether it was lost uniformly over the entire slope or was derived from certain parts of the slope, or whether the erosion resulted from raindrop impact or from the flow of runoff. An analysis of upland runoff generation and accumulation led FOSTER, MEYER \& ROMKENS (1975) to divide the erosion process into interrill and rill erosion. This allowed the sources of eroded soil to be separated into a portion originating from the top of the soil on interrill areas and a portion derived from a relatively greater depth in the rills. Interrill erosion is considered to be a uniform removal of soil, resulting mainly from detachment by raindrop impact, whereas rill erosion, which occurs only in a limited part of the slope surface, results from detachment by con-

ISSN $0341-8162$

c. Copyright 1984 by CATENA VERLAG, D-3302 Cremingen-Destedt, W. Germany 
centrated runoff (FOSTER, MEYER \& ROMKENS 1975, MEYER 1979). However, this division was still not completely satisfactory. In a study of upland runoff and sediment production in the Ardèche rangelands ROELS (1984) was able to distinguish three source areas: interrill, rill and pre-rill areas. Pre-rills, which result from the incision of interrill flow paths, are the initial stage in the development of rills.

By deepening and extending in length, they gradually change into rills. In each source area runoff is concentrated due to extreme surface roughness. The courses of pre-rill and rill runoff flows are permanent, while those of the interrill flows are not. The location of the prerill flow paths and of the rills remains the same from year to year. On the rough rangeland slopes pre-rills have lengths up to about $20 \mathrm{~m}$. Rills have a minimum length of $15 \mathrm{~m}$; they have a depth from 10 to $60 \mathrm{~cm}$ and a mean width of $50 \mathrm{~cm}$.

Pre-rill and rill runoff volumes are much higher than interrill runoff volumes (ROELS 1984). Pre-rill and rill erosion result essentially from soil detachment by concentrated runoff. Pre-rill and rill flow over rough bed surfaces can be characterized by laminar flow at low values of the Reynolds number ( $\operatorname{Re} \leqslant 100$ ). At higher Reynolds numbers the flow is either transitional or turbulent, depending on the surface roughness (see ROELS, in press). Interrill erosion results both from detachment by raindrop impact and from detachment by shallow concentrated flow intensified by drop impact. Neither interrill nor pre-rill erosion bring about a relatively uniform removal of soil (ROELS \& JONKER 1983). The aim of this paper is to present a first attempt at modelling interrill, pre-rill and rill erosion on a field or hillslope scale for individual storm events. In this approach the influence of raindrop impact and flowing runoff is expressed in terms of an erosivity factor. The net soil loss from each source area is related to a specific rainfall or runoff erosivity factor. Previously proposed rainfall and runoff erosivity factors (e.g. by FOSTER et al. 1977a, b) are used but a new erosivity factor is also presented. The validity of the single factor erosion model is tested for individual sites within a source area and for grouped sites representing a source area of increasing size. As the size of the source area increases, the percentage of the variation in net soil loss that is explained by erosivity decreases. Having calculated this decrease for each source area, one can then decide whether additional factors should be incorporated into the model in order to achieve a required degree of accuracy.

\section{MATERIALS AND METHODS}

The study was carried out in France on the rangelands of Ardèche drainage basin (Fig. 1). The research area, covering $8,250 \mathrm{~m}^{2}$, is limited to the upper part of a subcatchment slope (Photo 1). Mean annual rainfall, recorded over a period of 25 years, is $1036 \mathrm{~mm}$ (DE HEDOUVLLE 1980). The bedrock geology consists of Lower Cretaceous alternating limestones and marls (S.C.G., 1967) dipping gently (4 to $5^{\circ}$ ) towards the south-east. Differences in the resistance of these two rock types to denudation have produced a stepped slope profile; the mean slope angle is $17^{\circ}$. A lithic Xerochrept covers the bedrock (USDA 1975). The area under study is a Xerobromion grassland with scattered shrubs, which is associated with degenerate communities of the downy oak (Quercus pubescens; WOLKINGER \& PLANK 1981).

The slope is divided into two slope segments (mean slope angle of the upper slope segment is $15.1^{\circ}$, that of the lower segment is $18.5^{\circ}$ ); each slope segment has a length of $30 \mathrm{~m}$. $80 \%$ of the upper slope segment is covered by a vegetation canopy; for the lower slope segment the cover percentage is only 45 per cent. 


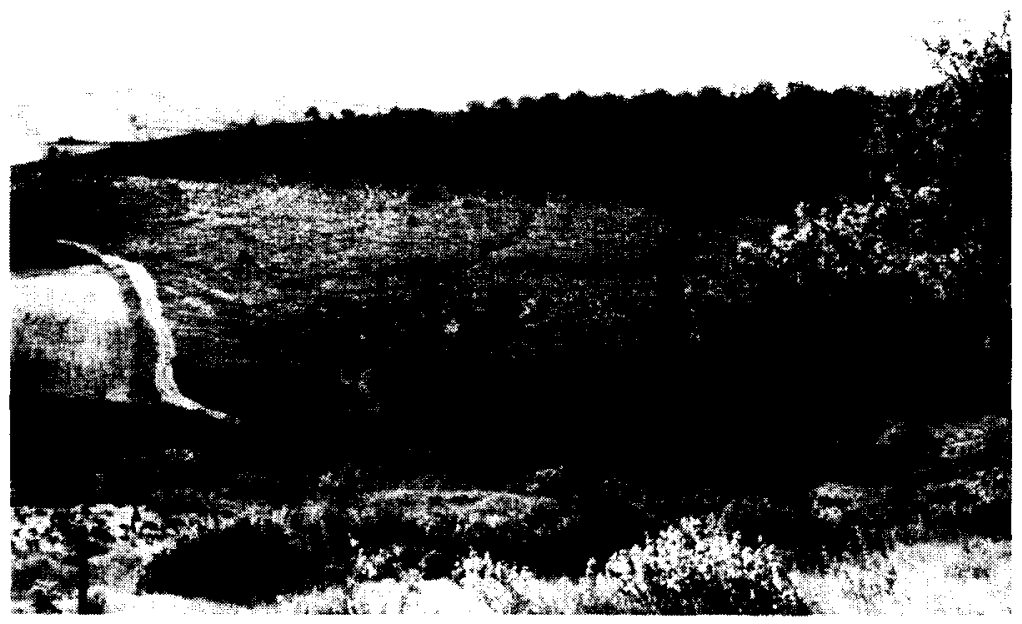

Photo 1: The study area.

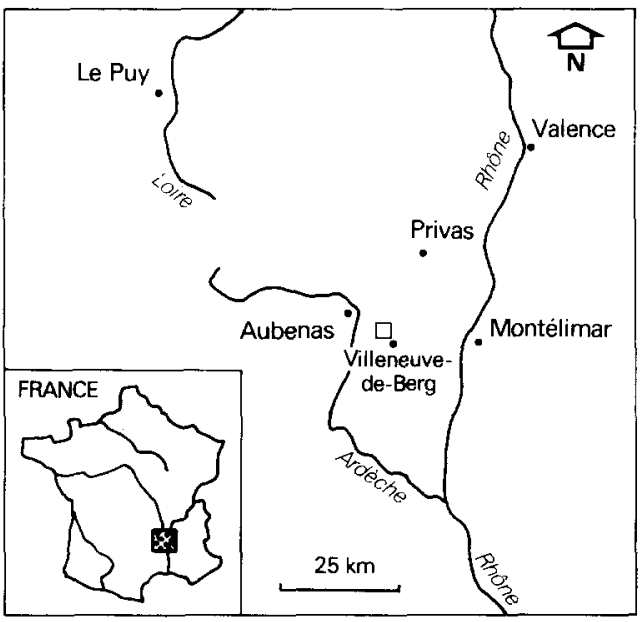

$\square$ The study area

Fig. 1: Location of the study area (after ROELS \& JONKER 1983)

Due to the irregular topography surface runoff does not flow parallel to the slope. Consequently plot boundaries will disturb the natural course of the flow. Therefore open plots instead of bounded plots were used to measure interrill, pre-rill and rill runoff carrying sediment. These open plots consist of several separate but adjoining modified Gerlach troughs (GERLACH 1967). The aluminium troughs, $0.5 \mathrm{~m}$ wide, are fixed in a base of poured concrete and attached to the slope surface by a strip of quick drying concrete. Each trough drains into a plastic container ranging in size from 0.5 to 25 litres. Accurate pre-rill and rill erosion data are acquired because the flow paths and microchannels empty themselves directly the troughs. Interrill erosion is measured in adjoining troughs. 


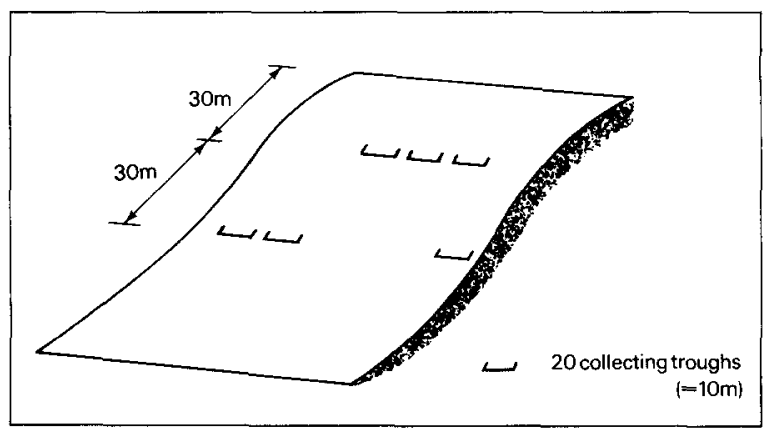

Fig. 2: Set-up of the troughs in the field (after ROELS \& JONKER 1983).

Sixty troughs were installed on each slope segment; they were arranged 'en echelon' to ensure a clear run to each trough from the crest (see Fig. 2 and also ROELS \& JONKER 1983). On the upper slope segment interrill erosion was measured in 54 troughs, pre-rill erosion in 5 troughs and rill erosion in 1, while on the lower slope segment 48 troughs caught interrill erosion, 7 caught pre-rill erosion and 5 rill erosion. The total area contributing to the upper 60 troughs was $695 \mathrm{~m}^{2}$, that contributing to the lower 60 troughs was $800 \mathrm{~m}^{2}$.

Splash erosion was measured in the field using 13 circular plastic collectors, $7 \mathrm{~cm}$ in diameter, placed flush with the soil surface. The entry of runoff from upslope was prevented by the construction of small concrete walls, about $50 \mathrm{~cm}$ from the collectors. The presence of these walls may limit the development of a water layer on the slope surface in the vicinity of the collectors. In consequence of this the impact of raindrops may be more effective in detaching soil particles. This modification of the natural splash erosion rate, however, is hard to quantify. Six collectors were placed on the upper slope segment and seven on the lower slope segment. The construction of the splash collectors is decribed in detail by BOLLINNE (1980). Of the 102 troughs gauging interrill erosion 13 troughs were selected for this study because at these 13 sites soil and cover conditions were comparable to the sites where splash erosion was measured. Pre-rill and rill erosion data were obtained from the 18 troughs mentioned above. Sequential samples of runoff and sediment were obtained by replacing the full plastic containers by empty ones. This was done by hand, which created many practical problems. As a result the number of storms, during which both the runoff volume and the sediment load were gauged accurately, was rather limited.

For each trough the total potential contributing area (micro-catchment) was measured on the basis of a micro-topography survey. A portable perforated reference frame was used in this survey. Measuring rods were inserted into the holes of the frame and the distances from the top of the frame to the slope surface were measured. From these measurements the microrelief was reconstructed. Error in the measurements is small. The accuracy of the entire survey depends on the number of measurements at each site and the number of sites in the entire area (sampling density). The micro-topography survey is very time-consuming.

The potential contributing area was used to calculate soil loss per unit of total area. It should be stressed that this potential contributing area is larger than the effective contributing area, which may vary from storm to storm. Calculations are based on data collected during nine spring and autumn storms between March 1981 and June 1982. These nine storms are representative of the local storm types and reflect well the range in rainfall characteristics 
Tab. 1: VALUES OF $\mathrm{EI}_{30}$ AND EAIM FOR THE RAINSTORMS UNDER CONSIDERATION

\begin{tabular}{lcc} 
Storm & $\begin{array}{c}\mathrm{EI}_{30} \\
\left(\mathrm{~J} \mathrm{~m}^{-2} \mathrm{~mm} \mathrm{hr}^{-1}\right)\end{array}$ & $\begin{array}{c}\mathrm{EAIM} \\
\left(\mathrm{mm}^{2} \mathrm{hr}^{-1}\right)\end{array}$ \\
\hline 1 & 758.3 & 62.1 \\
2 & 3772.2 & 520.0 \\
3 & 3203.2 & 106.6 \\
4 & 1683.0 & 143.5 \\
5 & 18682.2 & 1464.0 \\
6 & 6696.4 & 1062.0 \\
7 & 22391.9 & 1837.0 \\
8 & 111191.5 & 5976.0 \\
9 & 19235.1 & 906.8 \\
\hline
\end{tabular}

(e.g. values of EAIM ranged from 62.1 to $5976.0 \mathrm{~mm}^{2} / \mathrm{hr}$ for the nine storms under consideration (see Table 1) and from 13.2 to $6647.4 \mathrm{~mm}^{2} / \mathrm{hr}$ for all storms recorded between 1976 and 1982).

\section{CONCEPTUAL CONSIDERATIONS}

Recently developed models describe erosion as a function of the detachment of soil and the subsequent transport of sediment (MEYER \& WISCHMEIER 1969, FOSTER \& MEYER 1975). Erosion conditions may change from being detachment-limited to transportlimited, from storm to storm or even within a storm. Therefore detachment and transport are best considered in separate equations instead of being lumped in one long-term erosion equation; these separate equations must be given for each source area of sediment (FOSTER \& MEYER 1975, FOSTER et al. 1977a, b, KIRKBY 1981).

FOSTER \& MEYER (1972) and FOSTER et al. (1977a, b) presented a continuity equation for sediment transport. For one-dimensional quasi-steady state conditions this equation, which is applicable to each source area, is simplified to:

$$
\frac{\delta \mathrm{G}}{\delta \mathrm{x}}=\mathrm{D}
$$

where $\mathrm{G}$ is the sediment load in a source area $(\mathrm{gr} / \mathrm{m} \mathrm{s}), \mathrm{D}$ is the detachment rate in the source area $\left(\mathrm{gr} / \mathrm{m}^{2} \mathrm{~s}\right)$ and $\mathrm{x}$ is the downslope distance $(\mathrm{m})$ (FOSTER \& MEYER 1975).

There are three problems associated with the effective use of equation (1). First of all the boundaries of a source area have to be determined accurately. This is difficult (FOSTER 1981), especially when open plots are used. The second problem is that $\mathrm{D}$ is difficult to determine reliably. The mechanisms of detachment are still not well known. As a result various empirical approximations are used by different authors. Another complication is that the sediment load may be a function of detachment. No firm conclusion has been reached about this so far. Therefore there is no concensus on the necessity of expressing the interaction between $D$ and $G$ for upland erosion conditions (FOSTER \& MEYER 1975). The complexity of the model describing the erosion process increases when detachment is considered to be a function of the sediment load.

FOSTER \& MEYER (1975) have presented a conceptual equation for rill erosion expressing the interaction between $\mathrm{D}$ and $\mathrm{G}$ : 


$$
\frac{\mathrm{D}}{\mathrm{D}_{\mathrm{c}}}+\frac{\mathrm{G}}{\mathrm{T}_{\mathrm{c}}}=1
$$

where $D_{c}$ is the detachment capacity and $T_{c}$ is the transport capacity of the rill flow. This equation has not been verified experimentally. It has no physical basis and can only be regarded as a crude approximation of the interaction between $\mathrm{D}$ and $\mathrm{G}$.

Equation (2) further implies that the sediment transport mechanism requires only a short time to respond to changes in the flow characteristics (BENNET 1974). On the basis of empirical evidence FOSTER \& MEYER (1975) have presented solutions for equations (1) and (2), describing $D_{c}$ and $T_{c}$ in terms of flow shear stress and using a sediment transport equation. Since they found that the detached particles moved primarily as bedload, they selected the Yalin bedload formula, assuming that this equation is also applicable to shallow flows.

In order to simplify the calculations, several coefficients and variables in the equations (e.g. the Darcy-Weisbach friction factor) are taken to be independent of slope steepness or the distance along the slope. This approach poses some theoretical problems. First of all, the applicability of the Yalin equation needs to be checked.

Secondly, the simplifications involved must be fully warranted. The approach also has important practical limitations for many data are required and in spite of all the simplifications a great deal of calibration work is necessary. Hence, the model cannot easily be validated with field data.

It can also be assumed of course, that there is no interaction between D and G (FOSTER et al. 1977a, b; ONSTAD \& FOSTER 1975). Then the detachment rates for each source area can be integrated with respect to distance and time to yield the cumulative soil loss for a storm event; the total effect of the operative energy conditions on the detachment rate during each storm is reduced to an erosivity factor. Hence, the total soil loss for a single storm can be related to the erosivity of this storm. Due to this far-reaching simplification the model can be validated using field data.

Despite the fact that on the given irregular slope not all detached particles will be transported downslope (and therefore strictly speaking $D$ and $G$ are not independent) the utility of this straightforward modelling approach can be tested by relating the net soil loss from each souce area to a specific erosivity factor.

Although neither equation (1) nor the interaction between $G$ and D apply to rainsplash erosion, by analogy it seems worthwile to relate the net soil loss by rainsplash to a rainfall erosivity factor as well. This net soil loss is calculated following BOLLINNE (1980) using Ekern's formula (EKERN 1950).

The rain intensity and runoff volume (integrated with respect to time) alone are unsuited to be used as a measure of erosivity because responses of the detachment rate to the rainfall and runoff rate are likely to be delayed. However, during peak intensities and peak discharges these time lags are relatively small. In addition the major part of the total amount of sediment is produced during peak intensities and peak discharges. Therefore in this paper compound erosivity factors, which include peak intensity and peak discharge, are proposed. 


\section{RAINFALL AND RUNOFF EROSIVITY FACTORS}

Previous research (HUDSON 1981) indicated that soil loss by splash is well related to the parameter $\mathrm{EI}_{30}$ (the product of rainfall kinetic energy and the maximum 30 -minute intensity). Therefore $\mathrm{EI}_{30}$ (in $\mathrm{J} \mathrm{m}^{-2} \mathrm{~mm} \mathrm{hr}^{-1}$ ) is used as the rain erosivity factor for splash erosion. The kinetic energy of each storm is calculated according to HUDSON (1981):

$$
\mathrm{E}_{\mathrm{c}}=11.9+8.7 \log \mathrm{I}
$$

where $E_{c}=$ the energy of each class of rain intensity $\left(\mathrm{J} \mathrm{m}^{-2} \mathrm{~mm}^{-1}\right)$

$\mathrm{I}=$ the mean rainfall intensity $\left(\mathrm{mm} \mathrm{hr}^{-1}\right)$.

$\mathrm{E}$ is then multiplied by the amount of rainfall in each class (A ) and the energy is integrated for the whole storm. This total energy is multiplied by the maximum 30 -minute intensity to give the erosivity value. The most appropriate equation relating the $\mathrm{EI}_{30}$ factor to splash erosion is a power function (BOLLINNE 1980):

$$
\mathrm{G}_{\mathrm{S}}=\mathrm{p} \mathrm{EI}_{30} \mathrm{q}^{\mathrm{q}}
$$

Both values of $\mathrm{G}_{\mathrm{S}}$ and $\mathrm{EI}_{30}$ are transformed to logarithms to obtain the linear equation:

$$
\log \mathrm{G}_{\mathrm{S}}=\mathrm{a} \log \mathrm{EI}_{30}+\mathrm{b}
$$

Since the $\mathrm{EI}_{30}$ parameter is calculated entirely from rainfall characteristics, it does not reflect the runoff variability which is affected by (soil) conditions existing at the time of the storm. The soil under study is highly susceptible to crusting and as a result there is a large time variation in the intake rate of the soil (ROELS 1984). An erosivity factor describing both detachment and transport by drop impact and by interrill flow (influenced by drop impact) should combine a runoff and a rainfall factor. Several expressions for this erosivity factor were tested. The best fitting factor is the EAIM factor $\left(\mathrm{mm}^{2} \mathrm{hr}^{-1}\right)$ which is defined as the product of the excess rainfall amount $\mathrm{EA}$ (in $\mathrm{mm}$ ) and the maximum 5-minute intensity $\mathrm{IM}$ (in $\mathrm{mm} \mathrm{hr}^{-1}$ ). IM denotes the maximum value of the average intensity experienced in any 5-minute period during a storm. Rainfall intensities that exceed the intake rate of the soil produce overland flow. The amount of rain in these classes of rain intensity is added together to yield the excess amount of rainfall. The maximum 5-minute intensity is found from raingauge charts. The most appropriate equation relating EAIM to the net interrill soil loss is again a power function. Logarithmic transformation of data yields the equation:

$$
\log \mathrm{G}_{\text {ir }}=\mathrm{a} \log \mathrm{EAIM}+\mathrm{b}
$$

In the measurement set-up of this study it is possible to differentiate between the interrill runoff volumes and those of the pre-rills and rills for average or high energy storms. The volumes of the pre-rills and rills are much higher (ROELS 1984). Since this runoff is the main erosive agent, a runoff erosivity factor (REF) is needed for the prediction of pre-rill and rill soil loss. In this study the REF proposed by WILLIAMS (1975), ONSTAD \& FOSTER (1975) and FOSTER et al. $(1977 \mathrm{a}, \mathrm{b})$ is written as: 


$$
\mathrm{REF}=\frac{\mathrm{QPD}}{\mathrm{A}} /^{3}\left(\text { in } 1^{4} /{ }^{3} \mathrm{~min}^{-1} /^{3} \mathrm{~m}^{-2}\right)
$$

in which $Q=$ the runoff volume (1)

$\mathrm{PD}=$ peak discharge $\left(1 \mathrm{~min}^{-1}\right)$

$\mathrm{A}=$ unit area $\left(\mathrm{m}^{2}\right)$.

Contrary to the U.S. procedure which operates on a watershed-scale, and in which runoff prediction models are used to compute hydrographs and thereby runoff volume and peak discharge, in this study Q and PD are measured volumetrically. This deviating procedure was imposed by differences in the scale of operation and the degree of accuracy required. Under average storm conditions error in the measurements of $Q$ and $P D$ is estimated to be less than 10 and $5 \%$ respectively. The magnitude of error is somewhat greater for heavy storms; errors may then be as high as 15 and $7.5 \%$ respectively.

WILLIAMS (1975), ONSTAD \& FOSTER (1975) and FOSTER et al. (1977a, b) have shown that there is a linear relation between soil loss and the REF.

The equations selected to represent the relation between the net soil loss per unit area (in $\mathrm{gr} \mathrm{m}^{-2}$ ) and the erosivity factor for the various erosion types are therefore:

$$
\begin{array}{ll}
\mathrm{G}_{\mathrm{r}}=\mathrm{a} \mathrm{REF}+\mathrm{b} & \text { for rill erosion } \\
\mathrm{G}_{\mathrm{pr}}=\mathrm{a} \mathrm{REF}+\mathrm{b} & \text { for pre-rill erosion } \\
\log \mathrm{G}_{\mathrm{ir}}=\mathrm{a} \log \mathrm{EAIM}+\mathrm{b} & \text { for interrill erosion } \\
\log \mathrm{G}_{\mathrm{S}}=\mathrm{a} \log \mathrm{EI}_{30}+\mathrm{b} & \text { for rainsplash erosion }
\end{array}
$$

\section{STATISTICAL ANALYSIS}

The percentage of the variation in soil loss which is explained by the presented compound erosivity factors is determined for single measurement sites and for grouped sites representing a source area of increasing size. The most general linear model that is used to estimate the relation between soil loss $(\mathrm{G})$ and an erosivity factor $(\mathrm{Ef})$ has the form:

$$
\mathrm{G}_{\mathrm{ijk}}=\mathrm{a}_{\mathrm{ij}} \mathrm{Ef}_{\mathrm{ijk}}+\mathrm{b}_{\mathrm{ij}}+\varepsilon
$$

in which $\varepsilon$ is the error term.

This means that for each individual site $(j)$ in a source area (i) the regression is calculated from $\mathrm{k}$ observations ( $=9$ storms). If the sites are grouped to represent a source area, the relation between soil loss and erosivity can be estimated with a less detailed linear model of the form:

$$
\mathrm{G}_{\mathrm{ijk}}=\mathrm{a}_{\mathrm{i}} \mathrm{Ef}_{\mathrm{ijk}}+\mathrm{b}_{\mathrm{i}}+\varepsilon
$$

in which the sites within the source area are assumed to be the same. It is possible to test this assumption by comparing the percentage of the variation in soil loss which is explained by the general and by the less detailed linear models. Hence, in this application of general linear model theory (JOHNSTON 1978) one is able to study not only the relation between soil loss and erosivity but also differences between sites in terms of this relation.

Equations (5), (6), (8) and (9) are used in this statistical analysis. The constants a and $b$ in these equations are calculated by the method of least squares. Looking at the distribution of the error terms, we may assume that the error terms are independently distributed as a nor- 
mal distribution with a mean of zero and a variance of $\sigma^{2}$. All equations are very significant ( $\alpha$ $=0.001$ ).

Obviously, not all variation in soil loss measured at individual sites will be explained by erosivity and the percentage of explained variation will decrease further if the size of the source area increases. For the small rangeland area under study it is assumed that erodibility, topography or cover factors will contribute significantly to the variation in soil loss but that management and control practice factors will not. By analysing the decreasing explained variation in soil loss we can decide more effectively at which level of detail (or scale) the above-mentioned additional factors must be incorporated into equations (5), (6), (8) and (9).

\section{RESULTS AND DISCUSSION}

Values of the compound parameters $\mathrm{EI}_{30}$ and EAIM and of REF for the Ardèche field conditions are listed in Table 1 and 2 respectively. Table 3 shows that using the simple linear equations (8), (9), (6) and (5) a remarkably high percentage of the variation in net soil loss at individual sites can be explained by erosivity $(87,87,85$ and $88 \%$ for rill, pre-rill, interrill and rainsplash erosion respectively). The coefficients $a$ and $b$ in Table 3 indicate the intensity and the threshold of detachment; the diversity in these coefficients reflects the differences in detachment conditions within a source area. In view of the spatial variation in the relation between soil loss and erosivity among the individual sites a decrease in the percentage of explained variation in net soil loss is expected when these sites are grouped to represent a source area of either the upper or lower slope segment. Table 4 shows the values of the multiple correlation coefficient and those of $a$ and $b$ for the less detailed linear model. It turns out that $64,77,50$ and $49 \%$ of the variation in net soil loss is explained by erosivity. Hence, grou-

Tab. 2: RANGE IN MEASURED PRE-RILL AND RILL RUNOFF EROSIVITY VALUES

\begin{tabular}{|c|c|c|c|}
\hline \multicolumn{4}{|c|}{$\frac{\mathrm{QPD}^{1} /^{3}}{\mathrm{~A}}$} \\
\hline & & $\begin{array}{l}\text { Minimum value } \\
\left(\times 10^{-5} 1^{4} / \mathrm{min}^{-1} / \mathrm{m}^{-2}\right)\end{array}$ & $\begin{array}{l}\text { Maximum value } \\
\left(\mathrm{x} \quad 0^{-1} 1^{4} /^{3} \mathrm{~min}^{-1} / \mathrm{m}^{-2}\right)\end{array}$ \\
\hline RILLS & $\begin{array}{l}\text { I-18 } \\
\text { I-19 } \\
\text { I-20 } \\
\text { II-11 } \\
\text { II-12 } \\
\text { III-20 }\end{array}$ & $\begin{array}{r}96.8 \\
82.9 \\
264.0 \\
38.7 \\
108.0 \\
127.0\end{array}$ & $\begin{array}{r}179.0 \\
66.2 \\
307.3 \\
206.8 \\
220.5 \\
63.9\end{array}$ \\
\hline PRE-RILLS & $\begin{array}{l}\text { I-5 } \\
\text { I-14 } \\
\text { II-4 } \\
\text { II-5 } \\
\text { VI-7 } \\
\text { VI-10 } \\
\text { VI-15 } \\
\text { III-2 } \\
\text { III-13 } \\
\text { III-17 } \\
\text { IV-7 } \\
\text { V-4 }\end{array}$ & $\begin{array}{r}619.0 \\
659.0 \\
148.0 \\
111.0 \\
4.9 \\
22.5 \\
77.4 \\
52.5 \\
102.0 \\
9.6 \\
293.0 \\
119.0\end{array}$ & $\begin{array}{r}149.1 \\
200.9 \\
108.1 \\
72.6 \\
23.8 \\
8.1 \\
30.1 \\
2.3 \\
69.5 \\
4.0 \\
3.7 \\
3.8\end{array}$ \\
\hline
\end{tabular}


ping sites in order to represent a source area on a slope segment scale causes a 10 to $40 \%$ decrease in the explained variation in soil loss. There is a marked difference between the percentage of variation in soil loss explained by the pre-rill and rill erosion models ( $77 \%$ and $64 \%)$ and that explained by the interrill and rainsplash models $(50 \%$ and $64 \%)$. This difference is due mainly to the use of fixed (EAIM) or $\left(\mathrm{EI}_{30}\right)$ values but variable REF values at the various sites for separate storms. Consequently, part of the variation in soil loss can be ex-

Tab. 3: COEFFICIENTS a AND b OF THE EQUATIONS RELATING VET SOIL LOSS/UNIT AREA AND THE EROSIVITY FACTOR FOR INDIVIDUAL SITES. ML $L$ IIPLE $r$-VALUES ARE $0.93,0.93,0.92$, and 0.94 FOR RILL, PRE-RILL, INTERRILL AND RAINSPLASH EROSION RESPECTIVELY.

\begin{tabular}{|c|c|c|c|c|c|c|}
\hline & \multicolumn{3}{|c|}{ Lower slope segment } & \multicolumn{3}{|c|}{ Upper slope segment } \\
\hline rill erosion & $\begin{array}{l}\mathrm{I}-18 \\
\mathrm{I}-19 \\
\mathrm{I}-20 \\
\mathrm{II}-11 \\
\mathrm{II}-12\end{array}$ & $\begin{array}{r}9.30 \\
12.79 \\
2.65 \\
3.19 \\
3.66\end{array}$ & $\begin{array}{l}-12.08 \\
-3.05 \\
-8.40 \\
-4.23 \\
-5.25\end{array}$ & III-20 & 26.63 & -16.78 \\
\hline pre-rill erosion & $\begin{array}{l}\text { I-5 } \\
\text { I-14 } \\
\text { II-4 } \\
\text { II-5 } \\
\text { VI-7 } \\
\text { VI-10 } \\
\text { VI-15 }\end{array}$ & $\begin{array}{r}7.70 \\
7.23 \\
5.31 \\
11.82 \\
16.17 \\
9.56 \\
7.97\end{array}$ & $\begin{array}{l}-11.13 \\
-15.57 \\
-2.14 \\
-6.69 \\
-2.84 \\
-0.37 \\
-0.98\end{array}$ & $\begin{array}{l}\text { III-2 } \\
\text { III-13 } \\
\text { III-17 } \\
\text { IV-7 } \\
\text { V-4 }\end{array}$ & $\begin{array}{l}38.26 \\
14.12 \\
51.19 \\
58.64 \\
40.48\end{array}$ & $\begin{array}{l}-0.55 \\
-0.43 \\
-1.57 \\
-1.01 \\
-0.07\end{array}$ \\
\hline interrill erosion & $\begin{array}{l}\text { VI-12 } \\
\text { I-7 } \\
\text { VI-2 } \\
\text { I-3 } \\
\text { I-16 } \\
\text { VI-19 } \\
\text { VI-6 }\end{array}$ & $\begin{array}{l}1.40 \\
0.98 \\
0.72 \\
1.17 \\
1.08 \\
1.41 \\
1.34\end{array}$ & $\begin{array}{r}-3.73 \\
-1.85 \\
-1.50 \\
-1.98 \\
-2.42 \\
-4.47 \\
3.18\end{array}$ & $\begin{array}{l}\text { III-16 } \\
\text { III-18 } \\
\text { V-5 } \\
\text { IV-1 } \\
\text { V-10 } \\
\text { IV-18 }\end{array}$ & $\begin{array}{l}1.53 \\
1.11 \\
0.92 \\
1.31 \\
1.65 \\
2.67\end{array}$ & $\begin{array}{l}-4.32 \\
-1.93 \\
-2.97 \\
-4.31 \\
-5.68 \\
-8.15\end{array}$ \\
\hline rainsplash erosion & $\begin{array}{r}7 \\
8 \\
9 \\
10 \\
11 \\
12 \\
13\end{array}$ & $\begin{array}{l}0.74 \\
0.86 \\
1.42 \\
0.57 \\
0.94 \\
1.21 \\
0.55\end{array}$ & $\begin{array}{l}-2.11 \\
-2.35 \\
-5.28 \\
-1.17 \\
-2.47 \\
-5.37 \\
-0.91\end{array}$ & $\begin{array}{l}1 \\
2 \\
3 \\
4 \\
5 \\
6\end{array}$ & $\begin{array}{l}1.16 \\
0.78 \\
0.61 \\
1.01 \\
1.06 \\
1.17\end{array}$ & $\begin{array}{l}-4.29 \\
-2.90 \\
-2.72 \\
-4.60 \\
-5.84 \\
-5.75\end{array}$ \\
\hline
\end{tabular}

Tab. 4: COEFFICIENTS a AND b OF THE EQUATIONS RELATING NET SOIL LOSS/UNIT AREA AND THE EROSIVITY FACTOR FOR EQUATIONS GROUPED ACCORDING TO SOURCE AREA ON A SLOPE SEGMENT SCALE. MULTIPLE r-VALUES ARE $0.80,0.88,0.71$ AND 0.70 FOR RILL, PRE-RILL, INTERRILL AND RAINSPLASH EROSION RESPECTIVELY.

\begin{tabular}{llccc} 
& \multicolumn{2}{c}{ Lower slope segment } & \multicolumn{2}{c}{ Upper slope segment } \\
& $\mathrm{a}$ & $\mathrm{b}$ & $\mathrm{a}$ & $\mathrm{b}$ \\
\hline rill erosion & 3.85 & -2.00 & 26.63 & -16.78 \\
pre-rill erosion & 6.62 & -2.19 & 9.17 & 2.36 \\
interrill erosion & 1.16 & -2.73 & 1.33 & -3.92 \\
rainsplash erosion & 0.80 & -2.40 & 0.82 & -3.64 \\
\hline
\end{tabular}


plained by the variation in runoff erosivity. In addition the distribution of the erosivity and soil loss values used in the interrill and rainsplash models is compressed by the logarithmic transformation of the data. Under these circumstances grouping the individual observations also causes some decrease in the explanatory power of the less detailed linear model.

The explanatory power of the less detailed pre-rill and rill models is higher than that of the interrill and rainsplash models because variable erosivity factor values are used and the scale of measurement has not been transformed logarithmically. The variation in runoff erosivity is larger among the pre-rill sites than among the rills (see Table 2). Hence, the variation in soil loss is more likely to be explained by the variation in runoff erosivity for the pre-rills than it is for the rills.

The positive value of $b$ for the pre-rill erosion in the upper slope segment is due to regression and can no longer be interpreted as a threshold value of detachment.

Since the main contrast in soil erosion on a hillslope scale can be expected between upslope and downslope areas, grouping sites according to source area on this scale will result in a considerable decrease in the percentage of explained variation in soil loss. From the values of the multiple correlation coefficient shown in Table 5, we can conclude that this decrease ranges from about 10 to $70 \%$ depending on the type of erosion.

A striking result is that grouping all pre-rill sites on the slope hardly affects the predictive value of equation (9): $76 \%$ of the variation in soil loss can still be explained by erosivity.

Previous researchers have recognized that the influence of erosivity and other factors controlling the rate of erosion varies with the size of the area being considered (e.g. MORGAN 1980). The results given in Tables 3,4 and 5 demonstrate that this scale-dependence also varies with the type of erosion occurring. It would be logical to take account of the effect of scale on the influence of erosion-controlling factors in modelling soil loss but in current modelling practice this is ignored. For a particular source area of a certain size the use of only one erosion factor may be realistic, but for other source areas of the same size more information may be required. The simple linear rainsplash and interrill erosion models are very site-specific, whereas the rill and pre-rill models are not. Hence, the former models may not even be applied on a slope segment scale unless other factors are incorporated. On the other hand pre-rill and rill erosion models based on erosivity certainly are useful within the dimensions of a slope segment.

The most appropriate strategy for modelling soil erosion requires the selection of a level of spatial resolution, separation of source areas and identification of the most important factors influencing erosion at that level. Selection of these factors can be based on studies of the mechanisms of detachment and transport of soil particles by rainsplash and runoff. Rainsplash and interrill erosion on a hillslope scale will be very sensitive to modification of the rainfall characteristics by plant cover, to variations in slope, in grain size and in the degree of surface armouring. If spatially varying excess rainfall amounts or variable interrill runoff volumes are used in the interrill model it will become less site-specific. Accordingly, fewer additional factors then need to be incorporated in the model.

Tab. 5: COEFFICIENTS a AND b OF THE EQUATIONS RELATING NET SOIL LOSS/UNIT AREA AND THE EROSIVITY FACTOR FOR EQUATIONS GROUPED ACCORDING TO SOURCE AREA ON A HILLSLOPE SCALE. MULTIPLE r-VALUES ARE $0.63,0.87,0.64$ AND 0.43 FOR RILL, PRE-RILL, INTERRILL AND RAINSPLASH EROSION RESPECTIVELY.

\begin{tabular}{llr} 
& $\mathrm{a}$ & $\mathrm{b}$ \\
\hline rill erosion & 3.95 & 1.62 \\
pre-rill erosion & 6.45 & 0.27 \\
interrill erosion & 1.19 & -3.14 \\
rainsplash erosion & 0.77 & -2.77 \\
\hline
\end{tabular}


The pre-rill and rill erosion models are already less site-specific because the runoff erosivity factor values are influenced by other factors (e.g. slope length, crusting of the soil). Therefore, there is less need for additional information. A comparison of the runoff erosivity values for the pre-rills and rills shows that progressive rill development is accompanied by a decrease in the variation in runoff erosivity but not by a decrease in the variation in soil loss. Field observations indicate that these differences in rill erosion are due mainly to a variation in the availability of sediment among the rills. The conditions of sediment availability may vary from storm to storm. If the rill erosion model is applied on a hillslope scale additional information on the sediment availability will certainly be required. More soil particles are available in the pre-rills and less sediment is stored within the flow path. These conditions best meet the requirements of the model used.

If additional factors are introduced into either of the basic equations presented in this paper, a more extended linear model can be used. Note that the introduction of a large number of independent factors may cause problems of multi-collinearity. The utility of the extended linear model on different scales (from some $\mathrm{m}^{2}$ up to a hillslope) can also be tested by comparing a less detailed extended linear model (using grouped sites) with a general extended linear model (based on individual sites).

\section{CONCLUSIONS}

Some attempts have been made to develop a simple model that will predict soil loss on a hillslope scale for individual storms. A new modelling procedure is proposed that incorporates not only the relation between soil loss and one or more factors at various locations in different source areas but also the variation in this relation occurring between these locations. In the first instance the relation between soil loss and erosivity is considered.

About $85 \%$ of the variation in soil loss at individual locations in each source area is explained by erosivity. The influence of erosivity is found to vary with the size of the area considered. In addition this scale-dependence varies with the type of erosion occurring. If this effect is taken into account, soil loss modelling becomes much more effective. The rainsplash and interrill erosion equations presented are very site-specific. If these equations are to have a wider application many other factors will have to be incorporated. However, the rill and prerill equations are less site-specific and therefore fewer factors need be added. In the case of a pre-rill erosion model on a hillslope scale the use of only one factor, namely erosivity, can explain as much as $76 \%$ of the variation in soil loss.

\section{REFERENCES}

BENNET, J.P. (1974): Concepts of mathematical modelling of sediment yield. Water Resources Research vol. 10(3), 485-492.

BOLLINNE, A (1980): Splash measurements in the field. In: M. de Boodt and D. Gabriels (ed.), Assessment of erosion. Wiley and Sons, Chichester, 441-455.

EKERN, P.C. (1950): Raindrop impact as the force initiating soil erosion. Soil Science Society of America Proceedings 14, 7-10.

FOSTER, G.R. \& MEYER, L.D. (1972): A closed-form soil erosion equation for upland areas. Sedimentation (Einstein), (H.W. Shen, Publisher and editor, Fort Collins, CO) 12, 1-19.

FOSTER, G.R \& MEYER, L.D. (1975): Mathematical simulation of upland erosion using fundamental erosion mechanics. In: Present and prospective technology for predicting sediment and sources. Proc. of the 1972 Sediment Yield Workshop, USDA Sedimentation Lab., Oxford, MS, U.S. Agr. Res. Ser. (Rep.) ARS-S-40, 190-207.

FOSTER, G.R, MEYER, L.D. \& ONSTAD, C.A (1977a): An erosion equation derived from basic erosion principles. TRANSACTIONS of the ASAE 20(4), 786-682.

FOSTER, G.R., MEYER, L.D. \& ONSTAD, C.A. (1977b): A runoff erosivity factor and variable slope length exponents for soil loss estimates. TRANSACTIONS of the ASAE 20(4), 683-687. 
FOSTER, G.R. (1981): Conservation practices in erosion models. In: R.P.C. Morgan (ed.), Soil conservation, problems and prospects. Wiley and Sons, Chichester, 273-280.

GERLACH, T. (1967): Hillslope troughs for measuring sediment movement. Révue de Géomorphologie Dynamique 4, 173.

HEDOUVILLE, J. de (1980): Pluviométrie et thermométrie. Révue de la Société des enfants et amis de Villeneuve de Berg. Nouvelle série no. 35, 58.

HUDSON, N. (1981): Soil conservation. Batsford Academic and Education Ltd. London, 324 p.

JOHNSTON, RJ. (1978): Multivariate statistical analysis in geography. Longman. London, $280 \mathrm{p}$.

KIRKBY, M.J. (1981): Modelling water erosion processes. In: M.J. Kirkby and R P.C. Morgan (ed.), Soil erosion. Wiley and Sons. Chichester, 183-217.

MEYER, L.D., FOSTER, G.R. \& ROMKENS, M.J.M. (1975): Origin of eroded soil from upland slopes. In: Present and prospective technology for predicting sediment yields and sources. Proc. of the 1972 Sediment - Yield Workshop, USDA Sedimentation lab., Oxford, MS, U.S. Agr. Res. Ser. (Rep.) ARS-S-40, 177-189.

MEYER, L.D. \& WISCHMEIER W.H. (1969): Mathematical simulation of the process of soil erosion by water. TRANSACTIONS of the ASAE 12(6), 754-758, 762 .

MORGAN, R.P.C. (1980): Implications. In: M.J. Kirkby and R.P.C. Morgan (eds.), Soil erosion, Wiley and Sons. Chichester, 253-303.

ONSTAD, C.A. \& FOSTER, G.R (1975): erosion modelling on a watershed. TRANSACTIONS of the ASAE (19)2, 288-292.

ROELS, J.M. (in press): Flow resistance in concentrated overland flow on rough slope surfaces. Earth Surface Processes and Landforms. $11 \mathrm{p}$.

ROELS, J.M. (1984): Surface runoff and sediment yield in the Ardèche rangelands. Earth Surface Processes and Landforms Vol. 9, 371-391.

ROELS, J.M. \& JONKER, P.J. (1983): Probability sampling techniques for estimating soil erosion. Soil Science Society of America Journal 47(6), 1224-1229.

SERVICE DE LA CARTE GEOLOGIQUE (1967): Carte Géologique de la France. Feuille: Privas (échelle 1:80.000). Ministère de l'industrie, Paris.

U.S. DEPARTMENT OF AGRICULTURE (1975): Soil taxonomy, a basic system of soil classification for making and interpreting soil surveys. Agricultural Handbook 436. USDA, Washington D.C., 255-257.

WLLIAMS, J.R (1975): Sediment - Yield prediction with Universal Equation using runoff energy factor. In: Present and prospective technology for predicting sediment yields and sources. Proc. of the 1972 Sediment - Yield Workshop. USDA Sedimentation Lab., Oxford, MS, U.S. Agr. Res. Ser. (Rep.) ARS-S-40, 244-251.

WOLKINGER, F. \& PLANK, S. (1981): Dry grasslands of Europe. European Committee for the conservation of nature and natural resources. Graz, Austria, $56 \mathrm{p}$.

Address of author:

J.M. Roels, Department of Physical Geography, Utrecht State University

Heidelberglaan 2, P.O. Box 80.115

3508 TC Utrecht, The Netherlands 